\title{
Exiles, Displacements, and Relocation through the Trauma of Birth in Anak, Barcelona, Dubai, and Milan Imelda de Castro
}

\begin{abstract}
Culture is the identification of a person or community's origin. It is a set of values taught since birth and implemented throughout living. The variation of culture in the global setting is vast and allows other cultures to be affected by another. Filipino culture is very rich and passed down through generations, but Filipinos find it necessary to live and work away from their homeland. This study aims to prove the cultural ramifications experienced by the Filipino diaspora through selected Filipino movies. Anak, Barcelona, Dubai, and Milan shed light on the experiences of Filipino people overseas, especially their sufferings and sacrifices. With the guidance of Rank, Freire, and Propp, cultural ramification was observed in the portrayal of the selected movies which are not far from the real experiences of the Filipino diaspora.
\end{abstract}

Keywords: Diaspora, Overseas Filipino Workers, Cultural Ramification, Trauma of Birth 


\section{Plaridel Open Access Policy Statement}

As a service to authors, contributors, and the community, Plaridel: A Philippine Journal of Communication, Media, and Society provides open access to all its content. To ensure that all articles are accessible to readers and researchers, these are available for viewing and download (except Early View) from the Plaridel journal website, provided that the journal is properly cited as the original source and that the downloaded content is not modified or used for commercial purposes. Plaridel, published by the University of the Philippines College of Mass Communication is licensed under Creative Commons Attribution-NonCommercial-NoDerivatives 4.0 International License (https://creativecommons.org/ licenses/by-nc-nd/4.0/legalcode).

\section{How to cite this article in APA}

De Castro, I. (2020). Exiles, displacements, and relocation through the trauma of birth in Anak, Barcelona, Dubai, and Milan. Plaridel, 17(1), 153-173. http://www.plarideljournal.org/article/exilesdisplacements-and-relocation-through-the-trauma-of-birth-in-anak-barcelona-dubai-and-milan/ 


\section{Introduction}

Filipinos have been known since the 1970s to view overseas employment as a stepping stone for financial security (Asis, 2017). During the Spanish colonial period, Filipino families sent their children to study abroad as a symbol of prominence in society (Asis, 2006). Today, Filipino families send their members to work abroad and to try and uplift their financial condition. They are better known as Overseas Filipino Workers (OFWs). The personification of Filipino colonial mentality can be best described as the "American Dream." It is a cultural and economic phenomenon wherein the belief that working in the United States of America (or other developed countries) financially secures OFWs' families in the Philippines and is in itself considered an accomplishment in life (Sison, 2006). The persisting phenomenon is credited to mismatches between recent graduates and the job market, lack of working experience from the inadequate on-the-job training hours, and absence of tenure for a majority of workers (International Labour Organization, 2019). Reforms were implemented in the education system by introducing the junior-senior high school grade levels, but it has yet to produce results (Okabe, 2013). On the positive side, it provides a steady remittance of foreign currencies to the Philippine government which helps pay for its international debts. However, the its negative effects outweigh the positivity it brings. Filipino families are separated from their members, thus creating filial rifts among its members both due to the physical and emotional absence in the basic social group. Aside from this, many migrant workers suffer from discrimination and unjust treatment from their employers (Bayangos \& Jansen, 2010). These are the common conceptions about the sufferings of the Filipino migrant workers.

It is often reported in the media and gained voices addressing the government to improve the working standards in the country to discourage further deployment (Rutkowski, 2015). Away from the common conceptions, a less-known condition happens to Filipinos who are away from their home country and now live overseas. It is a condition called the "Trauma of Birth" coined by Otto Rank in 1924 (Rank, 1993). The article now aims to prove the Trauma of Birth through the cultural ramification of the Filipino Diaspora. It is important, therefore, to raise questions about Cultural Ramification among the OFWs being away from their homeland, the situation of the Filipino Diaspora, and the existence of the Trauma of Birth in the group. Specifically, the questions are (1) Is there Cultural Ramification among the OFWs based on the chosen films? (2) What is the situation of the Filipino Diaspora as portrayed in the movies? (3) Is there an existence of Trauma of Birth among the Filipino Diaspora? To answer the aforementioned questions, it has been determined as an imperative 
to provide a brief information about the Filipino Diaspora, cultural ramification, and its relation to the condition described by Rank through the plot in the Filipino movies titled; Anak, Barcelona, Dubai, and Milan whose storylines revolve around the lives of the OFWs and how migrant work affects them physically, emotionally, and culturally.

\section{Scope and Limitation}

The research is limited to the situations portrayed by the chosen films depicting the struggles of the OFWs during their residence in a foreign country. It does not include the situation brought by the contemporary national government, for example, the influx of foreign workers in the Philippines (Beltran, 2019). The analysis was posited mainly on the situation of the OFWs through the lens of the chosen movies. The utilized statistical or demographic data will be limited to what has been made available online by respective government agencies. It also aims to closely define OFWs as Overseas Filipino Workers, bearing either legal or illegal immigrant status who aim to seek better employment and opportunity. The research does not include the current issues that persist in Philippine society nowadays with the shift in its foreign policies. It is noteworthy to emphasize that the author intends to portray the life of the OFWs through the movies presented.

\section{Filipino Diaspora}

Diaspora comes from the ancient Greek word diaspeirein which means "to be scattered or dispersed" (Oxford Reference, 2020). The earliest usage of the Greek word can be found in Deuteronomy 28:25. It is a common term used to denote the group of people who are away from their homelands. Another definition has been coined by Milton Esman (1986); he wrote that the term denotes "a minority ethnic group of migrant origin which maintains sentimental or material links with their land of origin" (p. 316). Filipino scholars shed light on the status of Filipino Diaspora in reality. According to San Juan (2009), Filipinos leave the country inevitably due to the present poor conditions. To their disbelief, many Filipinos would only find themselves living a poorer life from maltreatment and employer abuse (Sayres, 2007). Contemporary to the movies' timeline, the Filipino Diaspora is the highest among the South East Asian countries wherein 3,400 Filipinos leave the Philippines daily to work overseas (San Juan, p.99). The benefit they bring to the country is insurmountable. For example, the migrant workers have sent a total amount of $\$ 33.5$ billion in 2019, a 3.9\% increase from the remittances recorded in 2018 at $\$ 32.2$ billion (Bangko Sentral ng Pilipinas, 2020). Due to their contribution, they have been nationally called as "modern-day heroes" by every administration since the "export" 
of Filipinos was institutionalized by the Philippine government as an official economic policy (San Juan, p. 100). OFW remittances are sufficient to keep the Philippine economy from crumbling and support the luxury and privileges of the ruling class which in proportion to the total population equates to only 1\% (ASEAN Post, 2018). It helps, therefore, reproduce a system of class inequality, sexism, racism, and national chauvinism across the international hierarchy of core and peripheral nation-states.

The situation can be more explained through the translated scholarly writing of Paulo Freire, The Pedagogy of the Oppressed. In his book, Freire (2000) states that there are two parties in the phenomenon. The two parties are composed of the oppressor and the oppressed. He claims that the oppressor has a consciousness of "being" and "haves." Being in the group that has the "haves," they crave to possess and dominate things, people, and the world itself. The oppressor would be treating their cravings as "objects" once they can possess it. However, the oppressor dislikes being confronted and prefers to have a relatively peaceful life of his own so he would design elaborate methods to keep his objects exploited (Freire, 2000). One of the elaborate methods is creating a myth wherein the oppressor would convince the object that it is a fixed situation that has to be accepted. About OFWs, it is indeed true that they live within the myth that they have to suffer overseas to secure their families in their homeland. Suffering became an acceptable situation for overseas workers while being under the oppression of their employers overseas.

But Freire (2000) does not only cover the observable scenario that happens between the oppressor and the oppressed. He also discusses Cultural Invasion. It is another method by the oppressor to set a temporary state of subjugation aiming to convince the oppressed of their inherent inferiority themselves. The oppressed are now forced to view the world through the lens of his superiors by learning their values and culture. By learning the ways of the oppressor, the oppressed stop thinking independently and behaves similarly to the former who develops a stronger grip on their lives. It creates cultural ramifications in the beings of the oppressed. Freire's idea shall bridge the main concepts of this paper which are Trauma of Birth and Cultural Ramification later on.

\section{Cultural Ramification and Trauma of Birth}

Cultural Ramification is a phenomenon that can be said to be an off-shoot from a change in one's culture or cultural branching. It happens when a group of people bearing a certain culture moves over to another area and integrates the culture from his homeland into the culture of the other area (Malewska-Peyre, 1982). If the definition provided by Hanna Malewska- 
Perye may be difficult to grasp, an idea raised by Czarina Wilpert (1982) has been built on Hoffmann-Nowotny's hypothesis. Wilpert argues that it is the apparent lack of opportunity which will equally result in the greater emphasis of cultural individuality and the co-option of attributed traits as positive by the marginalized group. For example, Ayumi Takenaka (2003) has published interviews of the Japanese-Brazilians and Japanese-Peruvians in the 1980s migration phenomenon in Japan. The half-Japanese migrants attested to a surprise with a mismatch of modern Japan against their expectations and some were upset by how they were denied acceptance into the typical conception of "the Japanese" (Takenaka, 2003). As a migrant narrated to Takenaka, "It's shocking because, in Peru, we looked down on Peruvians (non-Japanese Peruvians) and discriminated against them. But here in Japan, the Japanese discriminate against us" (p. 227). Another study authored by Daniela Carvalho (2003) further explains the cultural ramification during the same migration. Carvalho (2003) signifies "Japaneseness" as being socially constructed from "Blood', Japanese culture and language" (p.65) and quotes a respondent as saying, "We feel closer to the Nikkeijin (Brazilian-Japanese) because they look like Japanese. The Iranians and other foreigners do not look like us" (p.127). Yet whereas according to this rationale, those nikkeijins who are ethnically pure should be entitled to stake a higher claim to membership. Paradoxically, non-Japanese Peruvians have been found by Takenaka (as cited by Carvalho, 2003) to be generally more integrated than their ethnically Japanese countrymen. On measures such as the level of spoken Japanese, social involvement, and frequency of returning to their home country, the non-Japanese Peruvians were less socially distant from the majority of the Japanese.

Aside from Freire's published work, another related author will be mentioned to assist in bridging the concepts already mentioned. Vladimir Propp (1968), who analyzed Russian folk tales, has provided great insights on how folktales are to be examined. Despite Propp's analysis intended scope limited to his home country, he developed his morphology of the folktale which can analyze other stories not even within their original setting. Propp developed 31 narratemes or narrative units. The 31 narrative units have been further divided into four spheres. Propp named these four spheres as "Introduction," "Body of the Story," "Donor Sequence," and the "Hero's Return." Introduction and Body of the Story reflect the reality of the Filipino Diaspora since not everyone manages to reach the last two spheres (Propp, 1968). The first sphere includes "Absentation," "Interdiction," "Violation of Interdiction," and "Reconnaissance: Villain seeks something," "Delivery: Villain gains information," "Trickery: Villain attempts to deceive victim," and "Complicity: Unwitting helping of the enemy." These fragments of the 
first sphere can be summed up as the introduction of the situation and the setting. The so-called "heroes" interact positively with the "villain" with ulterior motives. It is similar to how the overseas Filipinos interact naively with their oppressors. Meanwhile, the second sphere signals the beginning of the main story and witnesses the departure of the hero on the quest. The third sphere will portray the hero's distinct qualities that make him titled as one. It is where the hero manages to overcome the trials and gains what he seeks which is necessary to the conclusion of the story. In the last sphere, the hero returns from the quest and solves the remaining problems for the story to have closure.

With Freire's and Propp's studies being discussed to serve as bridges between the chosen movies and Trauma of Birth, it is necessary, therefore, to discuss what is Rank's idea and how it is related to the aforementioned works. The Trauma of Birth is a concept coined by Otto Rank in 1924 which was translated into English five years later. He presents that human life is endowed with two basic instincts, namely the "life instinct" and the "death instinct" (Rank, 1993). Life instinct represents the person's desire for individuality and freedom while the death instinct represents our desire to belong to a family or community. In return, these instincts also include fears. The first fear is the fear of life which represents the fear of separation and loneliness while the fear of death, on the other hand, is the anxiety of losing our individuality in a group. Furthermore, Rank (1993) claims that the first anxiety that people experience in their lifetime is during their birth. It is the anxiety developed with how the infant becomes separated from their mother is a determinant of future anxieties or fears that the person would have later on (Rank). This trauma has become prevalent among the families belonging to the Filipino Diaspora. The trauma of birth as discussed by Rank gained a multiplier effect through the contemporary setting of oppression among the overseas Filipinos as seen through the movies focused on the study.

\section{Filipino Movies}

Movie 1: Anak

Anak(Santos-Concio, Santos, Dayrit, \& Quintos, 2000) is a moviefocused on a wife who took the reins from her husband to be the family breadwinner and then struggles to work overseas for a better life for her family. When she returns, she finds that her efforts have caused a rift between her and her children in this laidback family drama. Josie (Vilma Santos) is a mother of three children namely; Carla, Michael, and Daday from the Philippines. She was employed to become a nanny in Hong Kong for a wealthy couple, employment that lasted for several years. She is aware that she can earn 
more money in Hong Kong than she could at home but also has fears about how her absence will affect her children, especially when her husband died not long after she left. When Josie returns home, she has gifts for everyone and savings from her salary, which she plans to use to start a business. Her children, however, do not welcome her with open arms. The younger kids, Daday and Michael, are guarded around Josie but they eventually reconcile; Carla does nothing to hide her discontent for what she sees as her mother's heartless neglect of her family. Carla blatantly questions Josie's authority, starts dating boys she knows her mother wouldn't approve of, flaunts her burgeoning sexuality, begins using drugs, and has an abortion.

\section{Propp's Narratemes in Anak}

Sphere 1: Josie needs to work as a domestic helper in Hong Kong since her husband is unable to provide for their family. Her husband was supposed to work in Taiwan, but his employment was cut short since he was unable to endure the loneliness he experienced and felt like he will die if he stayed any longer. They feel the effects of poverty and find the need for someone to replace her husband who is unable to bring food to the table. Poverty becomes the villain for Josie and her family. Josie's children plead for her not to go but out of necessity, she goes on to her employment overseas. By leaving, she unwittingly cooperates with the villain to rip her family apart.

Sphere 2: Josie knows very well how dire their condition will become if she will not work overseas. Money is necessary for daily living. She then steels her resolve, applying for overseas work through legal ways. She gets hired for domestic worker employment in Hong Kong where she would take care of the family assigned to her.

Sphere 3: Josie suffers while being employed overseas. She longs for her family so much while being away from them. She soon earns enough and decides to come home, but her trials would not end there. While being away, a lot of things have changed. There are instances that the love of her children has faded throughout her absences like the special events in her children's' lives. There was a time it was Carla's birthday whom she was unable to greet because her employers were already home and she was just using the telephone secretly. She was also locked inside the apartment when her employers went on a vacation leaving her without any contact with the outside world; it was already too late when she finds out that her husband had passed away.

Sphere 4: Josie returns to the Philippines after her contract expires. Hoping to make up for all the lost time, she decides to treat her family to the fullest. However, she was unable to perceive that a lot would change during her absence. There were grievous incidents that happened while she was 
away and never told to Josie. It was now her task to mend her relationships with her children. After receiving the cold treatment from her children, her youngest daughter, Daday is the first one to open up to her mother and mend their relationship. The middle child and only son, Michael, is the next child who opened up to his mother. Due to poor grades, Michael lost his scholarship status which gave a discount on his matriculation. Michael was unable to tell his mother until he decides to tell her the truth. He sincerely apologizes for his failure, and this was the point where he was able to reconcile with his mother.

Josie had the hardest time reconciling with Carla, the oldest child. Carla was still immature and felt most victimized by the absence of her mother. Josie was unable to greet Carla on her birthday due to certain constraints by her employer, but Carla did not know about these. She questioned the absence of her mother in the wake of the funeral of their father. She believed that Josie pays more attention to become rich than being with her family. Carla would soon have multiple misfortunes while Josie is around. Then, the moment would come where Josie would finally confront Carla and make her feel the sufferings she endured just for them to have a comfortable life. The whole family reconciles and now, the children have a better understanding as to why Josie needs to go back overseas and work again.

Applying the ideas discussed earlier, it can be seen in this movie that Josie became a part of the Filipino Diaspora out of necessity. She has done it to secure the family's financial status at the price of the oppression she was bound to experience. It was her instinct that urged her to leave to avoid experiencing fear. Being poor, she was oppressed but she just simply accepted this situation believing that she is doing this for a better outcome. Meanwhile, the children who were left back in the Philippines long for their mother's presence in the family. Like their mother, their instinct was triggered and sought other means to dispel the fear they are feeling. The children were separated from their mother which is consistent with the idea of the trauma of birth. By birth, their mother is a necessary presence in their family. The mother had to leave though, and it caused repercussions on their family especially the children whose maturity has yet to come.

\section{Movie 2: Barcelona: A Love Untold}

The movie Barcelona: A Love Untold (Santos-Concio, Santos, \& Lamasan, 2016) portrays the story of Ely (Daniel Padilla), a man who cannot get over his past lover named Celine. He decides to travel to Barcelona where he is taking a master's degree while working at the same time. He then meets Mia (Kathryn Bernardo), a girl who sees Spain as a new beginning and looks very similar to Celine. After a series of mistakes in the 
past, she shortly relocates herself from her life in the Philippines to move forward and start anew. But their fates are still uncertain. Together, they go on a journey to discover the answers to their long-standing questions. The movie has received an accolade for being the best picture in the 65th FAMAS Awards 2017

\section{Propp's Narratemes in Barcelona: A Love Untold}

Sphere 1: In the movie, Ely and Mia had different villains in their lives. Ely has a past where he lost his lover, Celine, to an accident. Meanwhile, Mia lost her father's love and trust when she was labeled as a cheater in an examination. Ely seeks to fulfill Celine's wishes for him: to finish a master's degree in architecture in Barcelona. Mia, on the other hand, needs to redeem herself from the shame she has brought to the family by being successful in her attempt in the same place where Ely was. The protagonists in the story have their villains to face, so to speak. Ely's villain attempts to imprison him in the past, forever living a life of regrets while Mia's villain attempts to make her believe that working illegally in Barcelona would be her redemption from past mistakes. Both of them went to Barcelona believing the villains in their story were allies.

Sphere 2: Ely finds the necessity to fulfill Celine's desire as his atonement for always leaving her aside when he was still working away from her. Mia realizes the need to redeem herself to her father who was greatly ashamed when she was caught cheating. They both went to Barcelona to find what they seek and chose to live each day finding the answers to their "baggage" from the Philippines.

Sphere 3: The two protagonists in the story would soon face personal and interpersonal trials. Ely will face the difficulty of providing for his family in the Philippines and having a father who wanted nothing else but fulfills the wants of his late girlfriend's family wishes and that is to always remember Celine and achieved what she wanted for Ely. Meanwhile, Mia is faced with the difficulty of sustaining herself while just having a tourist visa. Fate allows them to meet each other in the area, and they cooperate in solving the other's dilemma. Their beginnings together might have been rough at first, but they soon live with each other in bliss. But the idea that Ely is with a person who bears the same physique as his former lover surprises everyone. News soon reaches the families of Ely and Celine in the Philippines that Ely had found a replacement for his late girlfriend. Ely is reminded by his father that the one supporting him is Celine's family and his employment should also be credited to them. However, his feelings cannot be restrained, and while on a video call with Celine's mother, she sees Mia together with Ely and is devastated upon seeing that the rumors were true. On Mia's side, her 
sister who knows what is happening to her was unable to keep her secret any longer and was forced to tell that Mia is working illegally in Barcelona instead of studying under a scholarship. It is during this period that the protagonists in the story would have to face their villains. Ely manages to overcome his villain by resolving not to live with Celine's ghost and move on without the fear of repercussion in the financial support provided by her family. He soon decides to talk to them personally regarding the matter with them. Mia decides to leave Barcelona and come home to start anew and seek forgiveness from her father.

Sphere 4: While in the Philippines, Ely confesses everything to Celine's parents and his father. Both of the fathers during the meeting understand Ely's perspective and reason for doing so. He is still alive and needs to live his life without Celine while Celine's mother might take a long time before she accepts Ely's decision. On Mia's side, she is welcomed by her family and the rift between Mia and her father is mended. They then both return to Barcelona and meet once again.

Regarding the plot and the ideas to be used in the research, it can be seen that the male protagonist had to move on from his former relationship. It is a signification that the character had his fear triggered by the instinct as mentioned by Rank. However, he managed to find someone who looks similar to Celine in a girl named Mia. His instinct urged him to approach Mia because she looks similar to whom he longs for. Meanwhile, Mia left the Philippines for Spain to start anew with her own life. It is similar to the common reason that they are unable to find satisfaction in their homeland. Has the place changed them? Yes, they were different people before coming to Barcelona. The culture that they possess has been changed slowly by the demands of their environment. From being onion-skinned, they have to learn to firm their resolve to survive. Were they oppressed by foreign employers? It has been portrayed sufficiently through the numerous jobs that Mia had to change since she could not bear that kind of treatment. The movie portrays clearly what the authors had mentioned in their scholarly works concerning the events that were bound to happen once a person leaves their homeland and settle in a foreign place.

\section{Movie 3: Dubai}

Dubai (Santos-Concio, Santos, Fuentes, \& Quintos, 2005) focuses on siblings Raffy (Aga Muhlach) and Andrew (John Lloyd Cruz) Alvarez, orphaned as kids and very much dependent on each other. Raffy has been working in a shipping company for nine years in Dubai. He supports his younger brother in the Philippines while helping his countrymen at the same time. His goal is to achieve a childhood dream which he shares with his 
younger brother, Andrew. Their dream is to eventually migrate to Canada as they see it as the land of opportunity. Raffy has had to suffer both the pain of being away from his homeland together with the different jobs he had to accept just to meet his daily needs while supporting Andrew. His beginning in Dubai was not as smooth as he thought it would be. He even had to suffer sleeping under a bridge to spend the night just because he could not afford any room to stay in. The Alvarez brothers are finally united when Andrew follows Raffy to Dubai. In Dubai, Andrew meets Faye (Claudine Barretto), one of his older brother's love interests. Andrew courts Faye and they become a couple despite their age difference. Faye becomes his guide, comfort, and lover. Andrew has a difficult time adjusting to life in Dubai. Being picky about the odd jobs being offered to him, he changes jobs often. Seeing his younger brother and former lover, Raffy realizes that his love for Faye is real. When Andrew discovers that Raffy still loves Faye, conflict arises between the brothers, almost breaking the ties that bind them. Soon, Faye realizes that she was impregnated by Andrew which entails grievous consequences in Dubai. Raffy comes to their aid and explains that in Dubai's legislation becoming pregnant while still unmarried would be severely punished. Faye rejects Andrew's marriage proposal just for them to stay together in Dubai and decides she would return to the Philippines together with her child. Meanwhile, the Alvarez brothers mend the rift in their relationship caused by their competition for Faye. Andrew goes to Canada while Raffy decides to stay. In the end, what they choose and achieve is not as planned but their experiences in Dubai lead to new beginnings in their lives.

\section{Propp's Narratemes in Dubai}

Sphere 1: The movie begins when the mother of Raffy and Andrew goes to Canada, leaving the siblings behind. The siblings grew up without their mother and developed strong personalities individually. However, these strong personalities will soon become their villains in the movie. Raffy's personality is composed of being helpful to others to the extent that he ends up with nothing for himself. Meanwhile, Andrew's personality is the typical personality of a younger sibling who looks up to the older as of the role model. The sibling's personalities brought them to Dubai since, during the time, employment in Dubai was very popular among the Filipinos. Both of them viewed it as their stepping stone to living in Canada just like their mother who had abandoned them. Their personality has led them to Dubai.

Sphere 2: The brothers needed to save enough money to migrate to Canada and fulfill their ultimate goal. Raffy is the first person to arrive in Dubai, leaving Andrew in the Philippines to finish his schooling. Raffy realizes that life overseas is very difficult. He needs to do things that he 
never experienced in the Philippines. However, he considers these all necessary because his ultimate goal is not to migrate to Canada first but assure the future of his younger brother by supporting him throughout his studies. Upon Andrew's arrival, the brothers are greatly overjoyed by their reunion but soon after, Andrew discovers that his brother was unable to save up a large amount of money despite his lengthy stay in Dubai since he was also helping the other Filipinos in their community. Andrew sees it as a form of betrayal of their promise to one another and accuses Raffy of being irresponsible and selfish. The two separate and live independently from one another. Soon after, Andrew overhears from a fellow Filipino about a certain man who slept with different women for shelter and sometimes slept under the bridge out of poverty since he sent all his money to his younger brother in the Philippines. From that point on, Andrew realizes that it was Raffy that they are talking about. Andrew discovers that what they needed was not the money itself but cooperation between him and his older brother. Andrew decides to mend his relationship with Raffy despite the events that led them to live apart.

Sphere 3: Swallowing his pride and desire for atonement, Andrew comes back to his brother and apologizes for all the sacrifices and hardships he had to make just for him to be what he is today. Raffy, on the other hand, realizes his mistake of being too selfless and requests everyone who owes him money to pay back even partially to fulfill their forgotten goal of his brother to migrate into Canada. By this time, the villains of our protagonists have been overcome since their pride and personality did not stand in their way of reconciliation.

Sphere 4: When every relationship among the characters was fixed, it is due time for the brothers to continue their plan of migrating. However, it was only Andrew who will be going to Canada since his older brother was able to find his place in Dubai already. The two do not argue anymore about their impending separation as they learn to accept each other's decisions as equally matured men and not as brothers. Their acceptance of each other proves to be the key to the story to find it's a satisfying conclusion.

It is one of the movies with stronger implications on the trauma of birth and cultural ramification. In this movie, it can be seen how living overseas could change a person whose determination has been founded since childhood. The absence of mother had struck the brothers to a great degree that their set goal is to migrate and always be together. But getting separated to sustain their daily living, each of the brothers changed according to the environment they have been exposed to. It can be seen why they had different priorities and thought processes. Their instinct made them strangers to each other but managed to reconcile after. 


\section{Movie 4: Milan}

The movie Milan (Santos-Concio, Santos, Samson-Martinez, \& Lamasan, 2004) is about the journey of naive Lino (Piolo Pascual) as he searches for his missing wife in Italy. Lino has a degree in engineering and married Mary Grace (Iza Calzado). Mary Grace decided to go and work in Milan for better compensation compared to the meager amount they may earn while locally employed. Time passes and Lino has had no news regarding the whereabouts of his wife. He decides to follow her in Milan without any certainty, bringing just a little money. He comes across Jenny (Claudine Barretto), an imposing personality among Overseas Filipino Workers, whose dreams of grandiose living have convinced her that romantic relationships are unnecessary. Jenny was originally from a welloff family until her father met his demise and caused Jenny's family to dive straight into poverty. Jenny's life was so impoverished to the extent that she had to work at a night club just to meet their needs. Lino is introduced to numerous employers and finds himself alienated from the personality of Filipinos in Milan who act and speak like Italians even in front of their countrymen. Most of the time, Lino complains about the unfair treatment of his employers and finds it very hard to accept the difference in culture and social standing. In a desperate quest for survival, the two find peace and affirmation in each other. The cooperative relationship between Lino and Jenny beautifully transforms into a love affair until their patience and faith are put to a test. Reality hits the couple as Milan changes everything. Lino soon finds out that Jenny had qualms upon telling him the truth that she was able to find his missing wife. Mary Grace entered Milan illegally and had been oppressed by the guide that helped them pass by border security. She was impregnated and lives in with a foreigner just to survive each day, a result of her failed attempt to find a better life. In the end, it does not matter that Lino found Mary Grace for he was able to find himself. Ultimately, it matters not for Jenny that she sacrifices in the name of love for she has learned to give in order to feel alive again. The movie had interview scenes from real Overseas Filipino Workers stating their experiences and suffering just to come to Milan.

\section{Propp's Narratemes in Milan}

Sphere 1: In the story, the main protagonists are Jenny and Lino whose fates are intertwined. In Lino's life, his wife goes missing after she decided to work overseas for a better opportunity. Meanwhile, Jenny's family is suffering from financial problems when her father suffered an unfortunate fate. These are the reasons why they needed to go to Milan for the answers to their problems. Lino faces the problem of looking for his wife and the 
loneliness it brings while Jenny faces the financial problem like other Filipinos who sought their fortunes to earn better overseas.

Sphere 2: Jenny arrives first in Milan before Lino. Jenny knows nobody there. She realizes that she needs to establish her footing in Milan, or she would not be able to survive at all. She befriends Italians who she would use to build up her network. She starts building her reputation among the community by being grateful for any jobs offered to her no matter how difficult it was. She earns respect from both the Filipinos and foreigners alike. Soon after, Lino arrives in Milan looking for his wife. The two cross paths when Lino is in dire need of help. Lino was ignorant about life overseas and carried his pride in his degree and license in engineering back in the Philippines. Jenny guides Lino around to help in his search for Mary Grace. Jenny further teaches Lino the trade and know-how to survive in Milan to improve his chances of staying longer since the area is so vast and Filipinos in the city would number in the thousands already.

Sphere 3: Jenny's patience with Lino would almost reach its threshold especially with how stubborn Lino; at the same time, it was an event that started the romance between the two characters. Lino soon realizes that the search for his missing wife is proving to be fruitless and he needed Jenny the most already. The two enter into a relationship while in Milan, but their old enemies would soon resurface. Lino would find out that Jenny had already discovered his wife's whereabouts and Jenny will have no choice but to have her brother, pickier, and more problematic than Lino, live with them. Their relationship goes through a rough patch when they lived apart due to their differences. Lino faces the fact that he can no longer live with his wifeshe had been impregnated by an abusive border guide who left her with no choice but to marry another foreigner to help raise the child born out of abuse. Jenny, on the other hand, has to deal with her brother who is just one of her burdens. But her brother soon leaves upon realizing that he does not need to be in Milan or that anything good will be achieved by his staying there any longer. Jenny is again left alone living overseas. Lino and Jenny will only meet in the consulate office when amnesty is provided for illegal Filipino workers in Milan from which both Lino and Jenny would benefit. However, their meeting during this time does not end up rekindling their relationship.

Sphere 4: Jenny returns to the Philippines while Lino decided to stay in Milan and accept his life in the place. He annuls his marriage with Mary Grace and becomes friends with her instead. After a while, Jenny returns to Milan and she meets Lino once again. From there, they decided to mend their relationship and live their lives together. 
The movie has more focus on the Filipino Diaspora and its effects on OFW families. Lino, whose wife went to Milan for better income, had been urged by his instinct to follow her. The lack of communication fed Lino's fears which consequently triggered his instinct to follow. His decision to go to Milan brought him the experience of being discriminated against by his foreign employers. Jenny was a witness to how Lino struggled but instead of defending Lino, she defended the oppression by the foreigner employers. She further justifies that they have to bear the brunt of discrimination because it is the right thing to do. By this, it can be said that Milan had changed Jenny into a willing victim of oppression since she perceived it as the norm for them. Meanwhile, Mary Grace was directed by her instinct to go with the flow and avoid dying in the border even at a great cost. Upon her arrival in Milan, she had been further directed by her instincts not to inform Lino about anything that had happened to her and sought to live with a foreigner who had approached and shown his intentions toward her. Among the movies presented, it can be said that this has the most number of pieces of evidence that prove the idea of the authors used in this study.

\section{Conclusion}

The chosen movies have a common theme of oppression in foreign land. The storylines of the movie were compared and signified the similarities that concur with the ideas presented by both Rank and Freire. It is important to do so in attaining the goal of the research which is to compare whether if mainstream news can portray the scenario of the Filipino Diaspora and its cultural impact on the people involved. Each protagonist mirrors the reality of the Filipino Diaspora. The reality became present by answering the questions posited at the beginning of the research. The questions in the study were answered through the following methods. The author looked at the set of analysis under the guidelines of scholarly works. The situation was also determined based on the movie portrayals and lastly, the results were verified by looking into the changes that happened among the characters through their instincts and fears. The findings were grounded on the ideas of Propp's Morphology of the Folk Tale, Paulo Freire's Pedagogy of the Oppressed, and Otto Rank's Trauma of Birth.

Upon the analysis of the movie with the guiding theories, the author derived the answer to the questions posited earlier. First, it was found through the lens of the movies that OFWs suffer from Cultural Ramification based on the different treatment they receive among the people of the foreign lands in terms of acceptance and respect. It can be rooted in two situations. The first instance is when the government lacks the proper implementation of the guidelines that they had drafted to protect the welfare of OFWs. 
Numerous reasons can cause this problem. However, the most common will be the lack of budgetary capacity by the sending country to oversee the implantation and welfare of their constituents. The second instance is when the person does not properly go through the legal process of migrating. It is not an unusual case that people would opt to reside as an illegal immigrant because of their economic limitations. Becoming an illegal immigrant entails numerous problems both for the person and their government. Being undocumented is similar to not letting your government know that you are in a foreign country. It will disallow them to exert their capabilities in terms of assisting. The second finding is about the status of the Filipino Diaspora overseas depends heavily on the employer they are with. Most of the time, they are employed by an oppressive employer that disregards their basic human rights and needs. Wanting to maximize the service of the OFW without paying appropriately, it intensifies the trauma of birth that the OFWs already have. Lastly, it can be observed that there is a Trauma of Birth among the characters since they decide on their actions based on the description provided by Rank with emphasis on how the people in the movies act upon their instincts.

These events among the protagonists prove the point of Rank (1993) that each individual has their instincts separated as the life and death instincts. These instincts would rewire the person's perception following the environment where the person resides. As we have seen, nobody among the protagonists in the stories had left for overseas without a certain reason. Most of them had been treated oppressively due to the difference in culture between the migrants and the local citizens. It can be said that within the storyline of each movie which was partly based on real stories, the sufferings of Filipinos caught up in the diaspora have been shown incompletely in media and the effects on the cultural aspect have lacked consideration. Being away from one's homeland and work for people who consider themselves as superior entails a path of oppression and cultural ramification. It has to be addressed accordingly for the years to come for these concepts were composed a long time already but it persists today.

It can be said that there is no perceived opportunity in the homeland for characters, and the only way out to poverty is to enter the state of oppression under the foreigners. The foreign employers view migrant workers as unequal to themselves or as second-class citizens. It is vividly observed in the hardships of each protagonist in the story. The mainstream news in the Philippines will only focus on the shallow issue of plain oppression of the migrant Filipinos whereas, in the movies, they provide additional insights for the audience to consider. Common scenarios such as the negative effects of illegal recruitment, oppression under their employers, and most 
importantly, the separation of family members are the usual cases reported in the media. However, the government actions taken were mostly directed for the prevention of illegal recruitment while only having a lukewarm response for the other two issues involved. Therefore, to remedy the issue of cultural ramification among the OFWs, dialogue between the people and the government is necessary, altogether with the government to government communication to provide for the welfare of the overseas Filipino workers as portrayed in the selected films. 


\section{References}

ASEAN Post. (2018, February 20). Overseas remittances remain crucial to Philippine economy. The ASEAN Post. https://theaseanpost.com/article/overseas-remittances-remain-crucial-philippine-economy

Asis, M. M. B. (2006). The Philippines' culture of migration. Migration Policy Institute. https://www. migrationpolicy.org/article/philippines-culture-migration

Asis, M. M. B. (2017). The Philippines: Beyond labor migration, toward development and (possibly) return. Migration Policy Institute. https://www.migrationpolicy.org/article/philippines-beyond-labormigration-toward-development-and-possibly-return

Bangko Sentral ng Pilipinas. (2020). Personal and cash remittances set record highs in 2019 at US\$33.5 Billion and US\$30.1 Billion. http://www.bsp.gov.ph/publications/media.asp?id=5290\&yr=2020

Bayangos, V., \& Jansen, K. (2010). The macroeconomics of remittances in the philippines. Ensayos Sobre Politica Ecónómica, 28(61), 18-58.

Beltran, M. (2019, July 12). Chinese workers flooding the Philippines jeopardize local employment and livelihood. The News Lens. https://international.thenewslens.com/article/121991

Carvalho, D. (2003). Migrants and identity in Japan and Brazil: The Nikkeijin. Migrants and identity in Japan and Brazil: The Nikkeijin, 1-202. https://doi.org/10.4324/9780203220719

Esman, M. J. (1986). Diasporas and international relations. In G. Sheffer (Ed.), Modern diasporas in internaitonal politics (pp. 333-349). St. Martin's Press.

Freire, P. (2000). Pedagogy of the oppressed (Third Anni). New York: Continuum. https://search.library. wisc.edu/catalog/999895194802121

International Labour Organization. (2019). Skills and jobs mismatches in low-and middle-income countries. https://www.ilo.org/wcmsp5/groups/public/---ed_emp/documents/publication/wcms_726816. pdf

Malewska-Peyre, H. (1982). Conflictual cultural identity of second generation immigrants. In H. Korte (Ed.), Cultural identity and structural marginalization of migrant workers (pp. 97-108). European Science Foundation.

Okabe, M. (2013). Where does Philippine education go? The "K to 12" program and reform of Philippine basic education. IDE Discussion Paper, 425, pp. 1-38. Institute of Developing Academies.

Oxford Reference. (2020). Ovwerview: Diaspora. Oxford Reference.Com - Oxford University Press. https:// www.oxfordreference.com/view/10.1093/oi/authority.20110803095716263\#: :text=The word is Greek\%2C and,all kingdoms of the earth\%27.

Propp, V. (1968). Morphology of the Folktale. In L.A. Wagner (Ed.) \& L. Scott (Trans.), Morphology of the folktale. University of Texas.

Rank, O. (1993). The trauma of birth. Dover.

Rutkowski, J. J. (2015). Microfinance and poverty in the Philippines. Philippine Social Protection Note, 9, 1-12. https://doi.org/10.13140/RG.2.1.3492.3123

San Juan, E. J. (2009). Overseas Filipino workers: The making of an Asian-Pacific diaspora. The Global South, 3(2), 99-129.

Santos-Concio, C., Santos, M. N., Dayrit, T. N. (Producers), \& Quintos, R. (Director). (2000). Anak. Star Cinema. 
Santos-Concio, C., Santos, M. N. (Producers), \& Lamasan, O. (Director). (2016). Barcelona: A Love Untold. ABS-CBN Film Productions.

Santos-Concio, C., Santos, M. N., Fuentes, T. V. (Producers), \& Quintos, R. (Director). (2000). Dubai. Star Cinema.

Santos-Concio, C., Santos, M. N., Samson-Martinez, M. (Producers), \& Lamasan, O. (2004). Milan. Philippines: Star Cinema

Sayres, N. J. (2007). An analysis of the situation of Filipino domestic workers. International Labour Organization. Retrieved from https://www.ilo.org/manila/publications/WCMS_124895/lang--en/ index.htm

Sison, A. D. (2006). Exploring national dimensions of third cinema. In Screening Schillebeeckx: Theology and third cinema in dialogue (pp. 35-62). Palgrave Macmillan US. https://doi. org/10.1057/9780230602106_3

Takenaka, A. (2003). Paradoxes of ethnicity-based immigration: Peruvian and Japanese Peruvian migrants in Japan. In R. Goodman, P. C., T. A., \& P. White (Eds.), Global Japan: The experience of Japan's new immigrant and overseas communities. Routledge Curzon.

Wilpert, C. (1982). Structural marginality and the role of cultural identity for migrant youth. In H. Korte (Ed.), Cultural identity and structural marginalization of migrant workers. European Science Foundation. 


\section{Grant Support Details}

Author Contributions: All research activities and writing were done by I. De Castro, Ph.D. The author has read and agreed to the published version of the manuscript.

Funding: This research was funded by the University of Santo Tomas Office of the Vice-Rector for Research and Innovation through the Research Center for Culture, Arts, and Humanities.

Acknowledgement: The author would like to thank Prof. Maribel G. Nonato, Ph.D., Vice-Rector for Research and Innovation, Prof. Joyce L. Arriola, Ph.D., former RCCAH Director, and Assoc. Prof. Maria Alexandra I. Chua, Ph.D., current RCCAH Director for their approval of the research project and generous support during the conduct of research until its publication.

Conflict of Interest: The author declares no conflict of interest. The funders had no role in the design of the study; in the collection, analysis, or interpretation of data; in the writing of the manuscript, or in the decision to publish the results.

\section{About the Author}

IMELDA DE CASTRO is a professor and fellow researcher from the Research Center on Culture, Arts, and Humanities at the University of Santo Tomas. She obtained her Doctor of Arts in Language and Literature Degree (with high distinction) from De La Salle University-Manila, where she also received an Academic Excellence Award. She teaches rhetoric, literature, translation, and research. She is also a regular member of the Humanities Division - National Research Council of the Philippines (NRCP) and an Executive Council member of the National Commission for Culture and the Arts (NCCA) - Language \& Translation. Recently, she was awarded the Dangal ng Wika 2020 from the Commission on the Filipino Language. (corresponding author: imeldapdecastro@gmail.com ) 
